\title{
Pure Erythroid Leukemia
}

National Cancer Institute

\section{Source}

National Cancer Institute. Pure Erythroid Leukemia. NCI Thesaurus. Code C7467.

Acute erythroid leukemia characterised by the presence of immature erythroid cells in the bone marrow (at least $80 \%$ of the cellular component), without evidence of a significant myeloblastic cell population present. -- 2003 